Indonesian Journal of Social Sciences Volume 13 No. 02, July-December 2021, page 74-83

\title{
Consumer learning behavior in adoption Tani Hub e-commerce
}

\author{
Maulavida Qholbyah Rahmah \\ Laksmi Muslimah \\ Address: Galaksi Bumi Permai Tahap 2 Blok L1 No.3, Indonesia \\ E-mail: olavidasatu@gmail.com
}

\begin{abstract}
As e-commerce develops in Indonesia, sales of fresh fruit and vegetable products move from physical stores to virtual markets through technological innovation. The adoption of e-commerce is marked by changes in purchasing behavior of fresh fruits and vegetables that originally relied on the senses, now mediated by a screen measuring at least 7 inches. Interaction between seller and buyer, or buyer with buyer also mediated. This condition does not require consumers to be able to see, hold and smell the product they want directly. When compared with conventional methods, the purchase of fresh vegetables and fruit through e-commerce has risks, namely uncertainty such as the physical quality of the product, taste or freshness. Consumers need knowledge and experience to reduce this uncertainty, where this knowledge and experience is obtained through a consumer learning process. This study describes the forms of consumer learning behavior starting from the beginning to get acquainted with adopting e-commerce. The research method used is qualitative with descriptive research type, and the method of data collection in the form of in-depth interviews with informants who are adopters of the Surabaya branch of the E-Commerce Tani Hub. This informant consists of a group of friends who have the same values, namely implementing a lifestyle and eating healthy food. The results of this study are in the form of learning behaviors shown by Tani Hub consumers through the process of information exchange with information sources that they consider credible, namely friendship circles and also primary information from the Tani Hub' company itself.
\end{abstract}

Keywords: consumer learning behavior; adoption of innovation; local fresh food; information exchange

Article History

Received: September 20, $2021 \quad$ Accepted: October 22, 2021

Cite this as: Rahmah MQ (2021) Consumer learning behavior in adoption Tani Hub e-commerce. Indonesian Journal of Social Sciences 13 (2):74-83. DOI 10.20473/ijss.v13i2.30108.

\section{Introduction}

\section{Consumer learning behavior}

Schiffman and Kanuk (2000) define the consumer learning process as the process by which a person gains knowledge and experience in making a purchase or consumption of a product that will later apply to similar behavior.

According to Sunarto (2003) in Rasyid (2019), behavioral learning is a process in which experiences with the environment lead to relatively permanent behavioral changes. Consumer learning is a relatively permanent change in behavior caused by consumer knowledge and experience on purchases and consumption that will be applied in the future (Sangadji \& Sopiah 2013). From some of these definitions, it can be seen that consumer learning shows that consumer behavior in buying or consuming products in the present is the result of a combination of their previous knowledge and experience.

In their book, Sangadji and Sopiah (2013) underline several critical assumptions in consumer learning. First, learning is a continuous process, meaning that consumers will always continue to learn with the availability of information wherever and whenever they are. This process requires that 
consumers will always gain new knowledge by reading, seeing, hearing, and connecting all of it with their experiences. That process will be used as a reference for them in deciding what they will buy and consume.

Second, learning is a process of seeking information intentionally. Although initially, it started by accident, this can continue on purpose as consumer interest develops after obtaining product information. Third, learning can be simply interpreted or interpreted more complicatedly related to solving consumer problems.

Finally, the output of learning is a relatively permanent behavior change. If consumers are satisfied with their learning experience buying something, they will repeat it with the same learning process.

Before entering the innovation adoption stage, consumers are encouraged to learn about new products. Consumer learning behaviors appear in the pre-adoption stages until the output of the learning is the adoption itself. Consumer learning becomes an analytical tool for forms of learning behavior carried out by consumers before finally adopting e-commerce.

Adopting e-commerce as a means of buying fresh food certainly differs from when you have to buy it directly at conventional sellers. The learning process occurs through two aspects, namely cognitive and behavioral. The cognitive aspect is related to information processing, while the behavioral aspect is related to classical, instrumental, and observational conditioning.

\section{Adoption of e-commerce in Indonesia}

The development of industry 4.0 provides unlimited space and opportunities for human activities from physical space to virtual space. Advances in information and communication technology have encouraged marketing to transform from conventional models to digital ones. According to data from the International Monetary Fund, eMarketer, eCommerceMILO, DigitalFilipino, Frost \& Sullivan, Hybris, VECITA, and A.T. Kearney Analysis summarized by IDEA (Indonesian E-Commerce Association) in 2013, Indonesia is the second-largest market in ASEAN after Singapore, with a population of 248 million, internet users of 39 million, and digital buyers of 5 million. Digital-based consumer purchase transactions are also shown through the frequency of consumers using ecommerce in 2018 (databoks.katadata.co.id). There are 31.6 million e-commerce users with a penetration of $11.8 \%$ and reaching 35.1 million with a penetration of 13\%. In 2019 and is estimated to increase in the following years.

There are several reasons why e-commerce is in great demand by the public, namely convenience for consumers and producers, where distance and time are no longer the main problems in transactions. According to Moon (2004), purchasing transactions via the internet have five benefits, including (1) offering superior quality, (2) prices that match the quality and service, (3) a wide selection of products, (4) saving time, and (5) convenience of shopping.

E-commerce itself is a trading activity mediated through the internet. E-commerce also has several characteristics. According to the Indonesian E-Commerce Association, it is differentiated based on the e-commerce business model, namely classified, marketplace and retail. Classified include Kaskus, Berniaga.com, Olx.co.id., and Tokobagus.com. Then the marketplace model is a business model where the website helps promote merchandise and facilitates online money transactions for online buying and selling actors, such as Tokopedia, Bukalapak.com, and Shopee. While the retail model is an online store with its website address (domain) where the seller has a stock of products/services and sells them online to consumers directly, one of which is Tani Hub.

\section{Tani Hub as e-commerce in the agricultural sector}

The emergence of e-commerce also provides space for the agricultural industry. According to a review by the Indonesian Ministry of Agriculture (cybex.deptan.go.id), based on Presidential Instruction No. 6 of 2009 concerning the development of the creative economy, one of the scopes of 
the creative economy in the agricultural sector is the development of information technology and multimedia for agriculture. In addition, local food products such as fresh fruit and vegetables, rice, meat, and eggs are also commodities developed through e-commerce. In contrast to traditional markets or physical fruit and vegetable stores generally, e-commerce cuts the sensory aspect where consumers can see and choose products directly. That has specific risks, such as fruit quality, taste, and freshness. But the presence of Tani Hub proves that e-commerce in this sector has a potential market among the Indonesian people. Especially those who are technology literate and certain groups of people and communities who apply healthy and practical lifestyles.

Given this uncertainty, consumers are encouraged to complete information related to e-commerce, the products they want, and how the services are provided so that what they order can reach them safely. Even though they are at risk, they are also encouraged to anticipate and minimize risks in their way. This study looks at consumer learning behavior that purchases fresh food through the Tani Hub ecommerce portal. Consumers in the digital era have the characteristics of finding and exchanging information about the products they need before finally deciding to buy.

Based on a review from the Ministry of Agriculture (pertanian.go.id) through its website, Minister of Agriculture Andi Amran Sulaiman said that Indonesia must achieve self-sufficiency in society by reducing imports. In the review, the Governor of Central Java, Ganjar Pranowo, also invited the Indonesian Agricultural Extension Association (Perhiptani) to optimize digital technology in assisting and assisting farmers. On another occasion, by Budi (ekonomi.kompas.com), Amran also campaigned that loving Indonesian fruit products mean loving red and white and loving Indonesian farmers. Thus, this leads to an increase in local food ingredients' sovereignty and encourages the Indonesian people to prioritize local food products over imports. That encourages researchers to find out how the learning behavior of Tani Hub consumers in adopting (accepting) e-commerce technology that mediates their activities to shopping for vegetables and fruits.

Tani Hub is one of the E-commerce that focuses on the local agricultural sector, which has developed quite significantly since its launch in 2015 and the first generation of agricultural e-commerce. Transactions made at one billion per month for three months from the start of the launch. Ecommerce that is engaged in the agricultural sector is oriented to connect farmers with consumers directly. According to Tani Hub's claim, this company is oriented towards improving the welfare of local farmers through the mechanism of cutting the distribution chain in which the selling price of local agricultural products can be adjusted to the production costs of the farmers. That provides a profit for farmers, which is $20 \%$ greater than distribution through middlemen.

Tani Hub is a company that plays a role in connecting local farmers with their consumers, including home consumers, traditional markets, supermarkets, or industries. In addition to providing an application platform that consumers can use to buy agricultural products, Tani Hub also provides a unique platform for farmers and their partners in finance and training for farmers who join. Farmers and partners who join include rice farmers, horticultural products, to chicken and egg farmers. According to Michael Jovan, Founder of Tani Hub at the time of its launch, it is inevitable that Tani Hub directly connects farmers and ranchers to their consumers, not secondhand.

Meanwhile, in terms of consumers, the buyers of agricultural products, Tani Hub targets business players, both industry and Micro, Small and Medium Enterprises (MSMEs). Tani Hub's main product focuses on organic rice because this organic product has attracted many repeat customers. Besides that, Tani Hub also has other local vegetables and fruits, both organic and non-organic. These products are also quite in demand when people start to intensify healthy lifestyles. In terms of technology, the targeted target is consumers who need local vegetable and fruit products, especially organic, who are technology literate. Hub carries the farm concept to the table, which means maintaining the quality of agricultural products to the dining table. 
At the beginning of 2015, there were pretty several start-ups in the agricultural sector. That is reasonable because the government has supported it with some e-commerce such as Happy Fresh, and a relatively new and gaining popularity, namely Tukangsayur.co whose scale covers major cities in Indonesia. However, other e-commerces are start-ups after the launch of Tani Hub, such as Tukangsayur.co, which was released in 2018, and Happy Fresh in 2016. So it can be said that they are followers of e-commerce that was launched previously. Among the various emerging e-commerce, Tani Hub positions itself as e-commerce that directly connects its consumers with local farmers. The following is Michael Jovan's interview with SWAOnline on swa.com, which Liliyah (2016) wrote.

"Yang kami tekankan adalah jika membeli di TaniHub artinya Anda membeli langsung dari petani, produk datang langsung dari petani,"

("What we emphasize is that if you buy at TaniHub, it means that you buy directly from the farmers; the products come directly from the farmers,").

E-commerce in the agricultural sector also has different concepts and characteristics like Happy Fresh, which has an online convenience store concept. It sells various kinds of essential food products, household and industrial needs with all kinds of brands, including fruit and vegetables, and supermarkets that do not focus on agricultural products. Tukangsayur.co focuses on the segment of housewives who need the services of providing vegetables and fruit from 'vegetable craftsmen' or vegetable traders, not from direct farmers.

In addition, Tani Hub branded itself as a platform that also empowered local farmers and agricultural sector activists. That is realized through education, training, and technology development programs for conventional farmers and for digital creators to participate in the mission to achieve balance in the agricultural sector in Indonesia. Some of the significances mentioned above produce different acceptances in the minds of consumers, and this is the reason for researchers conducting this research.

\section{Consumer groups care for the healthy eating lifestyle concept}

At the same time, the awareness of the Indonesian people to live a healthy life by consuming fruits and vegetables is also increasing. Based on a survey conducted by BPS in March 2016 regarding fruit and vegetable consumption, it was found that $97.29 \%$ of Indonesians consume vegetables, and three out of four residents consume fruit. Like a tit for tat, Endah Murningtyas, Deputy for Natural Resources and Environment of BAPPENAS at the 2011 Economic Study and Discussion forum, "13th Year Indonesia's Reform: Opportunities and Challenges of Agricultural and Industrial Development" stated that industrial clusters are a priority and have great opportunities for the sector. One of the Indonesian agriculture industries is the telecommunications hardware industry and the software and multimedia content industry.

In addition, the Government's goal of campaigning for local food self-sufficiency in Indonesia is to improve food sovereignty and public health and support local farmers. Communities or community groups, influencers, and so on have a role in disseminating education on applying the concept of healthy food consumption. The small scope is like a group of friends formed because of the common goals and habits of implementing a healthy eating lifestyle among the informants in this study. They do not form a community but have a general lifestyle that can unite them in a circle of friends. This circle of friends helps show how these Tani Hub adopters carry out consumer learning so that each of them wants to adopt Tani Hub.

Haninda Dwiwidya has also researched consumer learning in 2008 entitled Sources of Information and Learning Process of Female Visitors of Accessories Products at Strawberry Store Tunjungan Plaza Surabaya. In contrast to previous research, this study captures the phenomenon of digitalization in a series of learning and information exchange processes passed by consumers, while in previous 
Indonesian Journal of Social Sciences Volume 13 No. 02, July-December 2021, page 74-83

studies, digital communication and information technology have not become a trend. So this research seeks to explore novelty and the development of studies on consumer behavior in the era of ecommerce development.

\section{Methods}

This study aims to describe in-depth the forms of consumer learning behavior that occur in adopting innovation through the knowledge and experience of consumers purchasing fresh local food products through e-commerce. In this case, the object of research is the Tani Hub e-commerce. In comparison, the results of this study are in the form of a description of consumer learning behavior in adopting ecommerce. This study uses a qualitative method with a descriptive type, with data collection techniques in in-depth interviews. As a limitation, this study does not measure the level of diffusion that occurs in society on a large scale but invites the reader to see that there is a role for communication in friendship groups that lead consumers to the innovation in forms of consumer learning behavior adoption stage.

Based on this background, this research describes the forms of consumer learning behavior in terms of their cognitive and experience aspects. In adopting e-commerce, consumers go through a learning process, where the learning process results are in the form of actus behaviors in accepting an innovation. Table 1 has been presented the findings of consumer learning behavior.

Table 1.

Informant Demographics

\begin{tabular}{lccccc}
\hline \multicolumn{1}{c}{ Name } & Informant 1 & Informant 2 & Informant 3 & Informant 4 & Informant 5 \\
\hline Gender & Male & Male & Female & Female & Female \\
Age & 27 & 21 & 25 & 22 & 26 \\
Marital status & Single & Single & Single & Single & Single \\
Last education & S1 & SMA & D3 & SMA & S1 \\
Profession & Entrepreneur & College Student \& & Freelancer & College & Private \\
& & Freelancer & & Student & Sector \\
\hline
\end{tabular}

Researchers conducted in-depth interviews with four informants who were selected through the snowball technique, and one person was selected because they met the criteria as an informant. Indepth interviews were conducted in a duration range of 40 to 90 minutes. Before entering the primary interview, the informants were asked to tell their demographic background, interests in hobbies, and daily activities.

\section{Results and Discussion}

Figure 1 shows that in the circle of friends between Informants 1, 3, 4, and 5, who acts as an opinion leader who has a role in communicating Tani Hub's products and services is Informant 5 . Informant 5 has the character of an Early Adopter where he gets information from the source direct from Tani Hub. Then after he experienced the positive results of the experiment himself and shared his experience through social media, several of his friends were affected.

Informants 1, 3, 4, and 5 are informants who have a relationship with each other. In the first interview conducted by the researcher, namely to informant 1 , he told that he had previously been a division partner with informant five where they worked. Where they work is a local food processing industrycompany that produces healthy and organic food products. From the working relationship within the 
same company, indirectly, the values formed between these two informants are the same, namely bringing the values of healthy living.

Then, apart from informant 5, informant one also has a fairly close friendship with informant 3 , where this is based on the statement of informant three, who said that they had been close friends since high school until now. Both have the same hobby, namely cooking, and have an interest in local Indonesian products.

While the friendship relations between informants 3, 4, and 5 are peers. Even though they were born in different generations, the three of them always had a plan to gather together. In other words, this friendship relationship can be regarded as friendship. In the innovation diffusion stage, there are also networking or social networks that cover innovation adoption. The three of them also share meaning about products that are by the values they hold. One of them is the products they can buy at Tani Hub. This expected value that they have is one of the things that affect trust in each other. In fact, according to the confession of informant 4 , the first time his buying activity coincided with the purchase made by informants 3 and 5 .

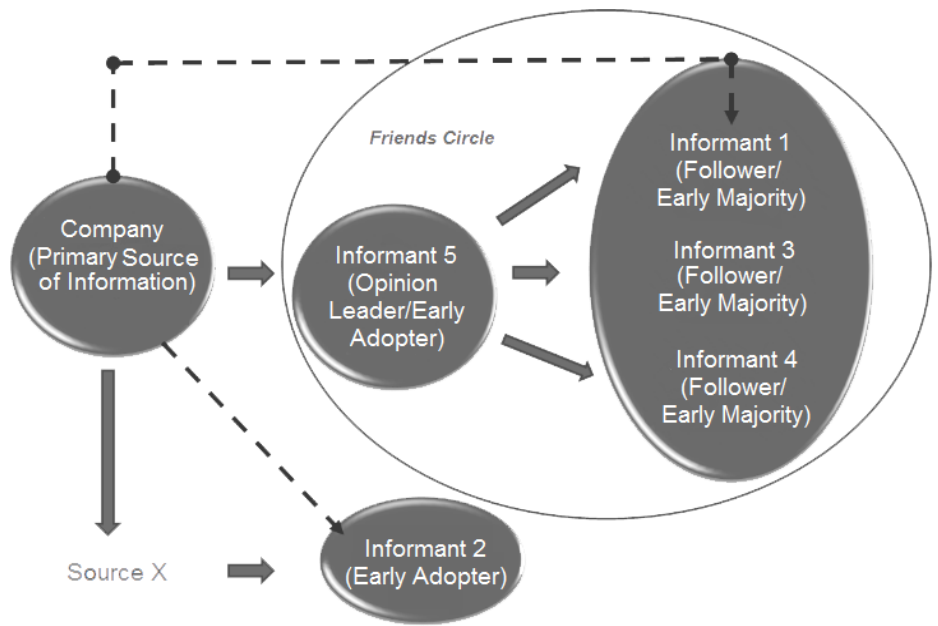

Figure 1.

Relations between informants

According to the story of informant 4 , the three of them are planning to develop a social project related to the women's community. It is through this real-life interaction that the three of them build mutual trust in each other. In simple terms, informants 1, 3, 4, and 5 have interpersonal relationships with each other, which make their understanding, experience, and emotions in trying a local fresh food product have in common.

Besides that, some of them are also motivated to continue the values built in this friendship group, and informants 1,3 , and 4 took the initiative to share their experiences and participate in influencing friends in other circles of friends to try this Tani Hub application. As their statement below.

"Aku juga pernah ngepost lewat story ku sih pas paket dari Tani Hub dateng. Eh terus pada tanya deh temen-temenku." (Informan 1).

("I also posted on my story when the package from Tani Hub arrived. Well, keep asking my friends." (Informant 1)). 
Indonesian Journal of Social Sciences Volume 13 No. 02, July-December 2021, page 74-83

\begin{abstract}
“Aku pernah ngerepost, dulu pernah bikin story instagram soal tampilan UI aplikasi Tani Hub di waktu pertama kali sebelum aktivasi akun Tani Hub. Bulan Januari waku itu. Itu karena aku suka sama copywritingnya dia. Selain SS-an, aku ngeshare tutorial aktivasi lewat screen recorder di IG story juga, biar ngga usah pke DM aku dan tanya-tanya lagi. Tinggal menjalankan seperti apa yang aku tutorialkan aja. Terus aku tag akunnya Tani Hub." (Informan 3).

("I've been reposting. I used to make an Instagram story about the UI display of the Tani Hub application for the first time before activating the Tani Hub account. That was January. That's because I like his copywriting. Besides the SS, I share an activation tutorial via screen recorder on IG stories, too, so you don't have to DM me and ask more questions. Just do what I've taught you. Then I tagged Tani Hub's account." (Informant 3)).

“..langsung kudownload aplikasinya, aku memutuskan untuk langsung beli, disaat yang bersamaan aku juga ngepromosiin ke temen-temenku satu kost-an untuk beli juga, jadi sekitar 4 orang itu beli. Aku juga buka jastip buat temen-temen satu kost." (Informan 4).

(“...I immediately downloaded the application, I decided to buy it right away, at the same time I also promoted to my friends a boarding house to buy it too, so about four people bought it. I also open a coat for my friends in the same boarding house." (Informant 4)).
\end{abstract}

From their explanations, it can also be seen that adopters whom Early Adopters initially influenced can also become a mouthpiece that can influence other friends to adopt as well. Unlike the case with informant 2, who did not relate at all to the other four informants. The decision of informant 2, he admitted, came from himself after having much information he obtained from his colleagues on social media who participated in uploading testimonials. However, he immediately looked for further information independently through the website, and the application he downloaded. However, he also admitted that the most influential thing for him was not the testimonials from friends, but the discounts. After further investigation, it turned out that informant 2 was a student who lived alone in Surabaya, where no family lived in the same city. Therefore he felt he had to be smart in dividing his finances. The main reason for buying it is because of the discounted price and time efficiency and financial effectiveness.

\title{
The journey of knowing until adopting Tani Hub
}

The five informants admitted that they know Tani Hub as e-commerce that innovates to connect farmers directly with their consumers. In other words, they did not know that there was e-commerce that focused on selling local agricultural products before. Before getting to know Tani hub, they still used the old way of obtaining local fresh food products, namely by visiting markets, vegetable vendors, supermarkets, or supermarkets.

They have adopted Tani Hub on average since 2019 until now, where most of them have the characteristics of being early majority adopters. Before adopting, they went through several stages, such as realizing Tani Hub e-commerce, the emergence of interest, the positive and negative evaluation process, and the first purchase trial.

\section{Accessed information sources}

The order of the sources of information they access is starting from uploads of close friends, colleagues, fellow community members, and Instagram ads. Then when they felt they had an interest in Tani Hub, the five informants were encouraged to visit Tani Hub's Instagram account and the Tani Hub website. When it was felt that the information had been fulfilled, and there was also a match between the needs or desires with what was offered by Tani Hub through its information media and recommendations from friends, the five informants were interested in downloading the Tani Hub application so that it can be seen that the sources of information accessed by the five informants include (1) testimonials and recommendations from co-workers, community friends, (2) Tani Hub Instagram, (3) Tani Hub Website, and (4) Direct Tani Hub Application. 


\section{Mental image formed in consumer's mind}

The information embedded in consumers' minds when they first get to know Tani Hub is an unboxing video that shows how Tani Hub packs and delivers its products to consumers and the condition of the products. While some mental images are formed in the minds of consumers before they enter the experimental stage, namely; (1) Tani Hub is remembered as e-commerce that provides a variety of local agricultural products, especially in the form of local fruits and vegetables organic and not. Where (2) local fresh food products are understood as healthy products and free from preservatives. (3) The price is entirely by the services provided by Tani Hub, where (4) the service is professional, especially in terms of packaging and supports the eco-green concept, namely using cardboard. In addition, consumers gain knowledge that (5) Tani Hub is e-commerce that plays a role in the welfare of local farmers and small business actors with programs to empower their farmer partners.

When this mental image has been formed from information processing, and it is also known that the results of the mental image formed tend to be positive, they are encouraged to enter the experimental stage. That is indicated by downloading the application, creating an account on the Tani Hub application, and buying it for the first time. At that time, they also decided to enter the experimental stage. Below, the discussion of recalling information will be explained about their response after making the first purchase.

\section{There are doubts on Tani Hub and how to anticipate uncertainty}

At the beginning of getting to know Tani Hub, informants who knew that this e-commerce provided various fresh food ingredients crossed their minds and emotions regarding concerns or doubts about the products being sold. Will the conditions be following their wishes, whether the taste and shape follow expectations, and others. It is also known that the Tani Hub e-commerce application does not provide a comment, review, or question column as one of the features in the application. Automatically enough confidence, education or information is needed for consumers to make a purchase.

Before adopting an innovation, all of the informants admitted that they were worried and had doubts. Considering that innovation has a different way of working from previous experience, namely the conventional way, of course, this requires some considerations and makes an effort to anticipate the uncertainty. One of the anticipatory efforts taken is evaluating how information is delivered, information availability, and the quality of information through the application. In addition, there is also an attempt to purchase a small quantity to minimize disappointment if the product that arrives does not meet expectations.

However, three out of five informants chose to try to believe it even though they also had doubts at the beginning of trying this e-commerce. At the same time, the doubts that are felt include the condition of the physical freshness of vegetable and fruit products and the time of delivery until the product reaches the hands of consumers. At the same time, anticipatory efforts were not carried out by every informant, only 2 out of 5, namely Informants 3 and 5. However, the five informants had an understanding of the consequences of shopping for vegetables and fruits online. So that even if they experience an unsatisfactory experience, they do not immediately refuse to adopt the application but accept it and continue to use it on other occasions. That is because the excellent service from Tani Hub and the suitability of the values that Tani Hub has with its consumers cover that ugliness.

\section{Consumers' responses to their dissatisfied experiences}

Almost every informant had an experience of dissatisfaction when entering the experimental stage for the first time. Dissatisfaction also occurred when the five informants reached the adoption stage. Some of the dissatisfaction experiences include (1) obtaining unripe vegetables or fruit, (2) obtaining unsweetened vegetables or fruit, and (3) obtaining unfresh vegetables or fruit. 
Indonesian Journal of Social Sciences Volume 13 No. 02, July-December 2021, page 74-83

From the experience of dissatisfaction, the response shown by each informant is reasonable and considers this a risk that each consumer must accept. However, they also still appreciate the professionalism of the services provided by Tani Hub to them, so that this makes them tend to accept and understand Tani Hub's reasons. From here, they decided to continue to adopt Tani Hub as ecommerce that serves them in purchasing local fresh food products.

\section{Conclusion}

The five informants have characteristics as early adopters and also an early majority, seen from the speed of adoption of Tani Hub's e-commerce. The adoption stage tends to be fast, where consumers do not need a long time to be willing to adopt e-commerce that they have just met and recognized. Most of the informants admitted that Tani Hub was the first agricultural e-commerce that they knew was engaged in the agricultural sector. Previously, they used to shop for vegetables and fruits conventionally, which after they experienced positive experimental results, they would become pioneers in the adoption of Tani Hub. All informants are active consumers in finding initial information independently, where initial references come from: work friends, close friends, community friends, Instagram, websites, and applications.

The mental images formed in the minds of the informants include: (1) Tani Hub provides a variety of local agricultural products, in the form of local and organic fruits and vegetables, (2) the local fresh products are healthy and free from preservatives, (3) the price is following the service, (4) the service is professional and supports the eco-green concept, and (5) is proud because it plays a role in the welfare and empowerment of local farmers. As consumers of Tani Hub, they do not worry about how Tani Hub maintains the quality of the products they order online, even though the products are fresh ingredients. All believe that Tani Hub is professional in maintaining the quality of their products.

From the cognitive aspect, the five informants are considered rational consumers, have many considerations to assess, and always follow technological developments. Most of the informants had doubts before trying the product through Tani Hub. The doubts are related to the physical condition and delivery delays. Most of the informants immediately believed and did not take any anticipatory efforts. The majority of informants had a dissatisfying experience when the Tani Hub package arrived, namely in the form of immature, not fresh, broken conditions and late arrival. Both informants who have never or several times experienced dissatisfaction continue to accept the consequences and still intend to adopt (use) Tani Hub as a platform to buy local fresh ingredients.

Exchange of information about Tani Hub e-commerce to consumers who have the same interest, namely in friendship groups. These similarities include a lifestyle of eating healthy food, lovers of organic and local culinary delights, and those who practice eco-living. Through this research, researchers can reflect that consumer learning behavior is a complex set of performances of cognition that includes processing information owned by consumers from searching, receiving, storing, and recalling their memories to generating rationalizations for their needs, desires, and desires decisions they take. In addition, the learning process is also obtained from the experience of consumers through their actual actions in evaluating, trying, and repeating purchases.

The learning that occurred in the early days of getting to know Tani Hub, both the product and its brand unity, provided additional insight and experience for consumers to the second or umpteenth purchase. These insights and experiences that they have had will be a reference for them to determine their following action. And as this learning period progresses, consumers do not escape the interaction and communication through digital platforms and interaction of friendship groups. 


\section{References}

Andi Amran Kobarkan Nasionalisme Lewat Kampanye Makan Buah Lokal (2017) [Diakses 29 Maret 2019]. https://ekonomi.kompas.com/read/2017/08/17/112710326/andi-amran-kobarkan-nasionali sme-lewat-kampanye-makan-buah-lokal?page=all.

Kementan Apresiasi Kinerja Penyuluh Pertanian dalam Mewujudkan Kedaulatan Pangan (n.d.) [Diakses 29 Maret 2019]. http://www.pertanian.go.id/home/index.php?show=news\&act=view\& id $=1906$.

Liliyah A (2016) Michael Jovan Bangun E-Commerce Buat Petani [Diakses 26 Februari 2020]. https://swa.co.id/swa/profile/michael-jovan-bangun-e-commerce-buat-petani.

Moon BJ (2004) Consumer adoption of the internet as an information search and product purchase channel: some research hypotheses. International Journal of Internet Marketing and Advertising 1 (1):104-118.

Pembeli Digital Indonesia (2017) [Diakses 11 Mei 2019]. https://databoks.katadata.co.id/datapublish /2018/03/27/berapa-pembeli-digital-indonesia.

Penyuluhan Pengembangan Ekonomi Kreatif Sektor Pertanian (n.d.) [Diakses pada 29 Maret 2019]. http://cybex.deptan.go.id/penyuluhan/pengembangan-ekonomi-kreatif-sektor-pertanian.

Rasyid N (2019) Pengaruh Motivasi, Persepsi, Pembelajaran dan Sikap Konsumen terhadap Keputusan Pembelian Produk Kosmetik Wardah di Kota Makassar. Skripsi, Universitas Islam Negeri Alauddin Makassar, Makassar.

Sangadji EM \& Sopiah (2013) Perilaku Konsumen Pendekatan Praktis. Yogyakarta: Penerbit Andi. Schiffman LG \& Kanuk LL (2000) Consumer Behavior. New Jersey: Prentice-Hall Inc. 